OPEN ACCESS

Edited by:

Dean Tang,

University at Buffalo, United States

Reviewed by:

Vemika Chandra,

Children's Hospital of Philadelphia,

United States

Yu Chen,

National Institutes of Health (NIH)

United States

*Correspondence:

Junyi Han

doctortonyhjy@tongji.edu.cn

Specialty section:

This article was submitted to

Stem Cell Research,

a section of the journal

Frontiers in Cell and Developmental

Biology

Received: 26 January 2021

Accepted: 26 April 2021

Published: 20 May 2021

Citation:

Du T and Han J (2021) Arginine Metabolism and Its Potential

in Treatment of Colorectal Cancer. Front. Cell Dev. Biol. 9:658861. doi: 10.3389/fcell.2021.658861

\section{Arginine Metabolism and Its Potential in Treatment of Colorectal Cancer}

\author{
Tao Du and Junyi Han* \\ Department of Colorectal Surgery, East Hospital, Tongji University School of Medicine, Pudong, China
}

Colorectal cancer is the leading cause of death from cancer globally. The current treatment protocol still heavily relies on early detection and surgery. The molecular mechanisms underlying development of colorectal cancer are clinically important and determine the prognosis and treatment response. The arginine metabolism pathway is hyperactive in colorectal cancer and several molecules involved in the pathway are potential targets for chemoprevention and targeted colorectal cancer therapy. Endothelial nitric oxide synthase (eNOS), argininosuccinate synthetase and ornithine decarboxylase (ODC) are the main enzymes for arginine metabolism. Limiting argininerich meat consumption and inhibiting ODC activity largely reduces polyamine synthesis and the incidence of colorectal cancer. Arginine transporter CAT-1 and Human member 14 of the solute carrier family 6 (SLC6A14) are overexpressed in colorectal cancer cells and contributes to intracellular arginine levels. Human member 9 of the solute carrier family 38 (SLC38A9) serves as a component of the lysosomal arginine-sensing machinery. Pharmaceutical inhibition of single enzyme or arginine transporter is hard to meet requirement of restoring of abnormal arginine metabolic network. Apart from application in early screening for colorectal cancer, microRNAbased therapeutic strategy that simultaneously manipulating multiple targets involved in arginine metabolism brings promising future in the treatment of colorectal cancer.

Keywords: arginine metabolism, transporters protein, signal pathway, colorectal cancer, stem cells

\section{INTRODUCTION}

Colorectal cancer is a highly prevalent and highly fatal disease worldwide, with a third incidence rate and fourth mortality rate (Brenner et al., 2014). While with decreasing trends for the incidence and mortality of colorectal cancer in many developed countries like the United States, the incidence and mortality in several developing countries, such as China, have continued to increase (Center et al., 2009a,b). These trends have been ascribed to their transition toward a so-called western lifestyle such as the consumption of high-fat diets and physical inactivity (Center et al., 2009b).

The molecular pathogenesis of colorectal cancer is heterogeneous including hereditary components and developing slowly through adenoma-carcinoma sequence in most cases. The molecular mechanisms underlying development of colorectal cancer are clinically important because they are associated with the prognosis and treatment response of the patient (De Sousa et al., 2013; Sadanandam et al., 2013). At present, the treatment of colorectal cancer is mainly surgery based comprehensive treatment, but the treatment effect of recurrent or metastatic colorectal cancer is still very limited (Cunningham et al., 2010; Pritchard and Grady, 2011). 
Recently, genomics and proteomics have made a lot of progress in the diagnosis and treatment of colorectal cancer (Manna et al., 2014), especially in the study of polyamines and their metabolism related molecules (Gerner and Meyskens, 2004; Manna et al., 2014).

It is well known that arginine is an original source of polyamines generation, and abnormal arginine metabolism has been characteristic of tumor cell metabolism. As a semi-essential amino acid in humans, arginine is critical for the growth of human cancers, particularly in those with chemoresistance and poor clinical outcomes. In addition to protein synthesis, arginine is involved in diverse aspects of tumor metabolism, including the synthesis of nitric oxide, polyamines, nucleotides, proline and glutamate. In addition, several enzymes and transport molecules in the arginine metabolic pathway such as ODC, CAT, and SLC6A14 were involved in the development of tumors, including colorectal cancer. There have also been some recent reviews on arginine metabolism in tumors, such as epigenetic arginine regulation in antitumor therapy and arginine deprivation. These reviews analyzed the role of arginine metabolism in tumors from various perspectives. However, studies have shown the two-faced effect of arginine. Some studies confirm that arginine enhances tumor growth (Selvi et al., 2019), others introduce it as an appropriate candidate for cancer treatment (Jahani et al., 2017). Currently, there is a lack of systematic review of the role of arginine metabolism in colorectal cancer. Besides, the effect of arginine metabolism in CRC is uncertain. In recent years, several studies on arginine metabolism in colorectal cancer have been emerged successively. For example, it has been found that limiting arginine-rich meat intake and inhibiting ODC activity can reduce polyamine synthesis and colorectal cancer incidence, and endothelial nitric oxide synthase (eNOS) inhibitors can inhibit CRC cell proliferation. In addition, miRNAs were an important class of molecules involved in multiple steps of tumor development (Niu et al., 2018). Thus, miRNAs targeting arginine and metabolic-related enzymes would be used as potential diagnostic markers or therapeutic targets. In order to better understand arginine metabolism and its role in diagnosis and therapy for colorectal cancer, this review discusses arginine metabolism pathway involved enzymes and its transporters in colorectal cancer. Although the literature on arginine metabolism in colorectal cancer was limited, we hope that this review will provide guidance for the diagnosis and treatment of clinical colorectal cancer, such as finding specific markers for the diagnosis and managing arginine intake in patients with high-risk factors for colorectal cancer.

\section{THE ROLE OF ARGININE AND ITS METABOLITES IN CRC}

Arginine is a semi essential amino acid for human body. The arginine is generated by two ways under physiological conditions, one is the ornithine cycle and the other is the membrane protein transport receptor to transfer extracellular arginine to the cell (Gerner and Meyskens, 2004). Many enzymes and arginine transporters were involved in the metabolism of arginine. Arginine could generate ornithine through Arg-1 and ornithine was involved in polyamine synthesis. Arginine could also generate guanidine through arginine decarboxylase (ADC) and then participate in cell signal pathway. Guanine can be produced under the action of arginine deaminase (ADI) or nitric oxide synthetase. Besides, arginine could be synthesized again through the arginine succinate synthetase (ASS1) and arginine succinate lyase (ASL) (Szlosarek, 2014). Once the metabolism of arginine is broken, it is easy to cause tumor (Battaglia et al., 2014; Paz et al., 2014).

Arginine and its metabolites play an important role in the development of CRC. Studies have found that limiting argininerich foods could reduce the incidence of colon cancer. Recently, it has been reported that that CRC cell lines could not grow in arginine free medium in vitro, and DNA replication stopping and cyclin expression down-regulation were also identified, which could be reversed by exogenous arginine supplementation (Alexandrou et al., 2018). In addition, expression of ASS was significantly increased in CRC, while overexpression of ASL was negatively correlated with prognosis (Huang et al., 2015, 2017).

Arginine is the substrate of eNOS. It was found that eNOS in CRC was related to tumor vascular invasion (Chhatwal et al., 1994), and eNOS inhibitors could inhibit the proliferation and apoptosis of CRC cells through downstream molecules (Altun et al., 2013). ODC could decompose the metabolites of arginine into polyamines, which was necessary for the development and proliferation of CRC (Gerner and Meyskens, 2009). The expression of ODC in CRC was significantly increased, which could regulate the cell cycle process and promote tumor progression (Nakanishi et al., 1993). Meanwhile, ODC inhibitors could reduce the occurrence of colon polyps and adenomas (Battaglia et al., 2014). In addition, arginine transporters were also involved in the development of CRC. SLC6A14 expression was up-regulated in CRC which involved in the regulation of mTOR signaling pathway, thereby regulating cell proliferation and energy metabolism (Gupta et al., 2005). Inhibition of CAT1 could reduce the survival rate of tumor cells and inhibit the expression of EREG, which was a key factor in the transformation from inflammation to colon cancer (Camps et al., 2013). Furthermore, some drugs that induce the expression of SAT1 spermidine/spermidine N1 acetyltransferase (SAT1 or SSAT) had therapeutic effects on inflammatory CRC, indicating that they might also be involved in the regulation of the progress of CRC (Evageliou and Hogarty, 2009; Goodwin et al., 2011).

\section{INTRACELLULAR ARGININE METABOLIC PATHWAY IN CRC AND ITS IMPLICATION FOR THERAPIES}

L-arginine has been a long known substrate of eNOS or nitric oxide synthase 3 (NOS3), with resulting metabolic products of L-arginine-NO being nitric oxide (NO) and Citrulline (Figure 1). Recent studies demonstrated that cancer cells have a higher eNOS expression, as eNOS is required for maintaining permanent tumor growth via Ras-activated PI3K-Akt signaling pathway (Fukumura et al., 2006; Lim et al., 2008). Clinical studies on 


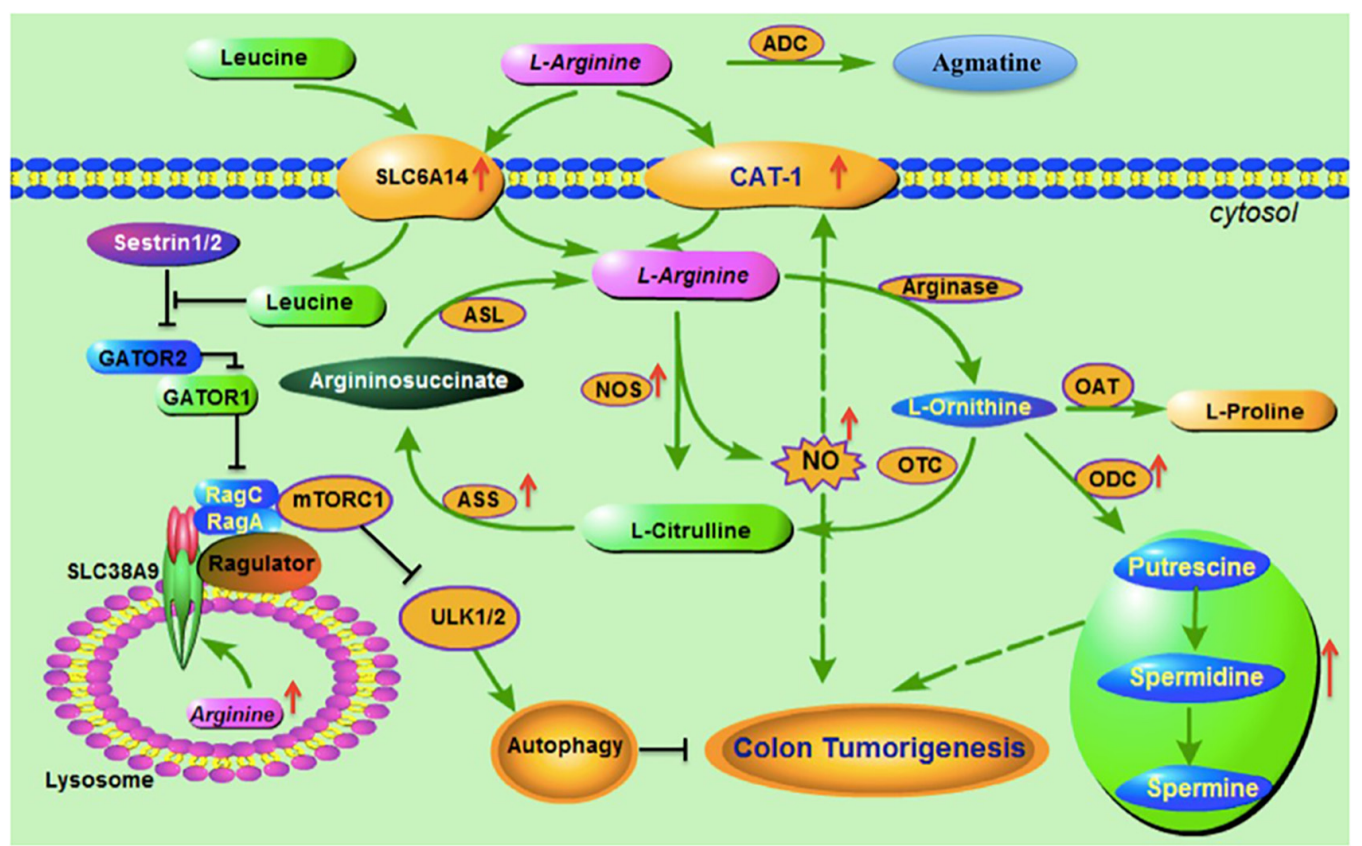

FIGURE 1 | Arginine metabolic pathways and association with colorectal cancer. Before L-arginine enters into cells, arginine decarboxylase (ADC) catalyzes the arginine to generate agmatine. Arginine transporters SLC7A1 (CAT-1) and SLC6A14 are the main transporters responsible for arginine transmembrane transportation. Both CAT-1 and SLC6A14 are highly expressed in colorectal cancer. SLC6A14 is also responsible for transportation of leucine. Nitric oxide synthase (NOS) catalyzes the cytosol L-arginine to generate L-citrulline and Nitric oxide (NO), and the latter is reported to upregulate CAT-1 expression. L-citrulline is converted into argininosuccinate via Argininosuccinate synthetase (ASS), which is a rate-limiting enzyme in arginine recycle biosynthesis. Argininosuccinate lyase (ASL) catalyzes argininosuccinate to produce endogenic L-arginine. Arginase catalyzes the L-arginine to generate L-ornithine, which has three metabolic pathays: (1) converting to L- citrulline via Ornithine transcarbamylase (OTC); (2) to generate L-proline via Ornithine aminotransferase (OAT); and (3) to produce polyamines (including putrescine, spermidine and spermine) via ornithine decarboxylase (ODC). NOS, polyamines and ODC are all reported upregulated in colorectal cancer and contributing to colon tumorigenesis. SLC38A9 is a component of the lysosomal arginine sensing machinery and sestrin1/2 is the sensor of cytosol leucine, both of which control mTORC1 and regulate autophagy and involve colon tumorigenesis.

human colon cancer samples suggest that high eNOS expression can be positively correlated with tumor cell vascular invasion (Chhatwal et al., 1994), as well as in trophoblast cancer (Ariel et al., 1998). Besides, an eNOS inhibitor L-NIO could increase the antiproliferative, antiangiogenic and apoptotic effects of E7080, a tyrosine kinase inhibitor, on CRC cell in vitro. In was found that blocking the eNOS phosphorylation could inhibits tumorigenesis, while overexpression of eNOS enhanced the nitrosylation and activation of Ras proteins in vitro and vivo (Lim et al., 2008).

Arginine as is a substrate of eNOS is thus crucial for the tumor-drivinng PI3K-Akt-eNOS (wild-type)-Ras pathway, which further explains the increased arginine catabolism in cancer cells. Cellular recycling mechanisms are in place to provide sufficient substrate (citrulline) for arginine synthesis with help of intracellular argininosuccinate synthetase (ASS) and argininosuccinate lyase (ASL) (Figure 1). Loss of ASS in several tumor entities renders them arginine auxotrophic, e.g., hepatocellular carcinoma, malignant melanoma, malignant pleural mesothelioma, prostate and renal cancer (Ensor et al., 2002). In contrast, several platinum sensitive tumors, including primary ovarian, stomach and colorectal cancer, are characterized by ASS overexpression (Delage et al., 2010). This explains the inutility of arginine deprivation in colorectal cancer therapy.
L-arginine catabolized by arginase (ARG) produces ornithine, which is further broken down by ornithine decarboxylase (ODC) to polyamines (Figure 1), such as putrescine, which is essential for CRC development and proliferation (Gerner and Meyskens, 2009). In earlier studies, it was found that increased polyamine expression in colorectal cancer tissues was associated with increased ODC activity, and the ODC protein and mRNA expression were significantly higher in CRC tissue compared to paired normal tissues (LaMuraglia et al., 1986). It has been proved that ODC was engaged in G1/S progression, and the cell cycle modification by agmatine through ODC inhibition was considered indirect while by interfering with cyclins expressions, agmatine exerted a direct effect (Nakanishi et al., 1993). Furthermore, its dose-dependent inhibitory effect has been demonstrated on some cancers including colon cancer and hepatocellular carcinoma (Patil et al., 2016). Thus, it is comprehensible why an overexpression of ODC has been proven in CRC (Goodwin et al., 2011) and neuroblastoma (Evageliou and Hogarty, 2009; Battaglia et al., 2014), confirmed that ODC might promote the colorectal cancer progress (Patil et al., 2016).

Studies have found that adenomatous polyps (APC) tumor suppressor gene and KRAS gene play important roles in the process of polyamine production and colorectal tumorigenesis. Increased ODC transcription and polyamine synthesis were 
detected in APC mutant mice. At the same time, the use of ODC inhibitors can significantly reduce the incidence of colon polyps and adenoma (Battaglia et al., 2014), and can also be used for the chemoprevention of prostate adenocarcinoma and skin cancer (Manni et al., 2004; Xu et al., 2008). There is evidence that limiting the meat consumption and inhibiting ODC activity can significantly reduce polyamine synthesis and incidence rate of colorectal cancer with ODC1 GA/AA genotype, compared to GG (Zell et al., 2012).

\section{POLYAMINE METABOLIC PATHWAYS AND THEIR POTENTIAL THERAPEUTIC TARGETING IN CRC}

Polyamine is a small molecular weight organic polycation, which can combine with negatively charged substances such as RNA, miRNA and protein, and participate in the transcriptional regulation of gene expression (Gerner and Meyskens, 2004; Battaglia et al., 2014; Paz et al., 2014). In addition, polyamines can modify the eukaryotic translation initiation factor-5A (eIF5A) and affect the transcription and translation of downstream oncogenes and tumor suppressor oncogenes (Scuoppo et al., 2012; Paz et al., 2014).

The metabolism of intracellular polyamines is strict regulated in cells. When these balances are broken, it is easy to lead to tumorigenesis such as in colorectal cancer (Battaglia et al., 2014; Paz et al., 2014; Figure 1). Spermidine/spermidine catabolism is regulated by three major enzymes, including spermidine oxidase (SMO), spermidine/spermidine N1 acetyltransferase (SAT1 or SSAT) and N1 acetylpolyamine oxidase (APAO). The drug sulindac and other NSAIDs can induce SAT1 expression in human cell and mouse models, which may be one of the reasons for the treatment effect of inflammatory colorectal cancer (Evageliou and Hogarty, 2009; Goodwin et al., 2011). Recently, it has been found that overexpression of SAT1 can rapidly reduce the levels of spermidine and spermine in cells, thereby inhibiting cell protein synthesis and preventing cell growth (Mandal et al., 2013). These results indicate that SAT1 has a certain prospect in the treatment of colorectal cancer. Similarly, a variety of catabolic enzymes involved in polyamine catabolism, including SSAT, APAO, and SMO, are also potential targets for the treatment of colorectal cancer.

\section{ARGININE TRANSPORTERS IN COLORECTAL CANCER}

Arginine can shuttle across the cell membrane through a variety of transporters ( $\mathrm{Lu}$ et al., 2013, Figure 2). The most common arginine transporter family is that of $\mathrm{Na}^{+}$-independent cationic amino acid transporters (CAT), which consists of CAT-1, -2A, -2B, -3, and -4 (Malandro and Kilberg, 1996; Palacin et al., 1998). The studies are focus on cat- 1 and cat- 2 , while the function and specificity of CAT-3 and cat- 4 are not clear (Closs et al., 2006). Another arginine transporter is the sodium- and chloride-dependent transporter, which is encoded by member 9

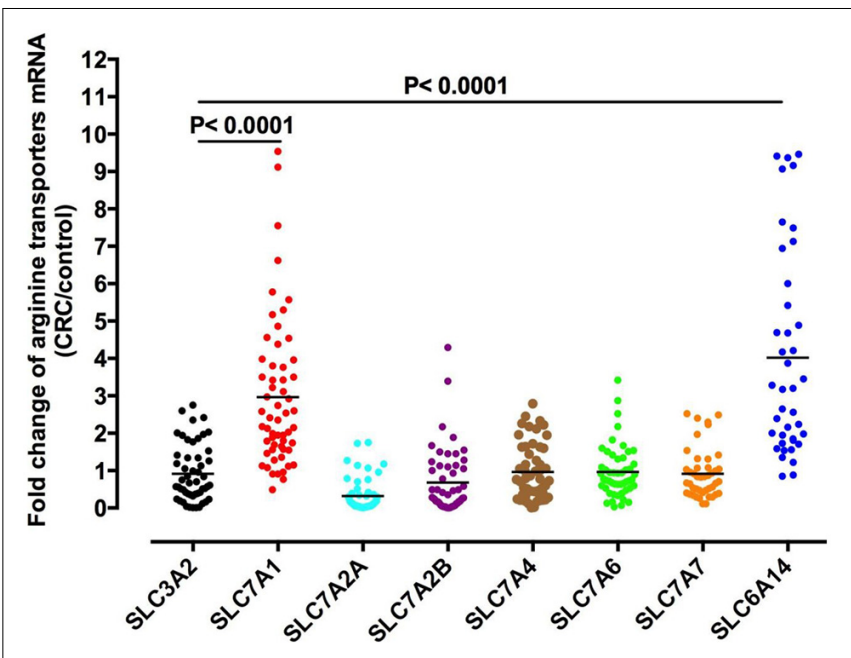

FIGURE 2 | Arginine transporters expression in colorectal cancer. The mRNA levels for each arginine transporter in colorectal cancer and adjacent normal tissues of 90 colorectal cancer patients were measured by qPCR. The expression of SLC7A1 and SLC6A14 genes were significantly upregulated in colorectal cancer patients.

of solute carrier family 6 (SLC6A14 gene). In colorectal cancer, CAT-1 expression was negatively correlated with pathological grade (Figure 3 ).

Camps et al. (2013) found that siRNA down-regulation of CAT -1 expression can reduce the survival rate of cancer cells, and significantly inhibit the expression of growth factor Epiregulin (EREG), which is a key factor in the transformation of colon from inflammation to tumor. There are some differences in arginine transporters in different cells. For example, CAT -2 is mainly expressed in some immune cells such as macrophages (Morris, 2010), while CAT-1 is specifically expressed in colorectal cancer (Su et al., 2004). Since CAT -1 is a membrane protein, specific monoclonal antibodies can be used to neutralize cat-1 and inhibit the uptake of arginine by CRC cells, so as to achieve the purpose of tumor treatment.

SLC6A14 was found to be highly expressed in colorectal tissues (Gupta et al., 2005), due to the increased demand of tumor cells for leucine and arginine (Karunakaran et al., 2011). The leucine is an activator of mTOR pathway (Laplante and Sabatini, 2012; Figure 1), which can form two protein complexes mTORC1 and mTORC2, playing an important role in tumors associated with metabolic disorders. The expression and leucine transport of SLC6A14 are regulated by PKC (Closs et al., 2006), which is a downstream molecule of mTORC2 and an important signal molecule regulating tumor cell proliferation (Zell et al., 2012). Based on the above results, the inhibition of arginine uptake by SLC6A14 may have potential clinical significance. Human member 9 of the solute carrier family 38 (SLC38A9) has recently been identified as a component of the lysosomal amino acid (particular arginine)-sensing machinery that regulates the targets of rapamycin complex 1 (mTORC1) (Jung et al., 2015; Rebsamen et al., 2015; Wang et al., 2015). The mechanistic mTORC1 integrates the presence of growth factors, energy 

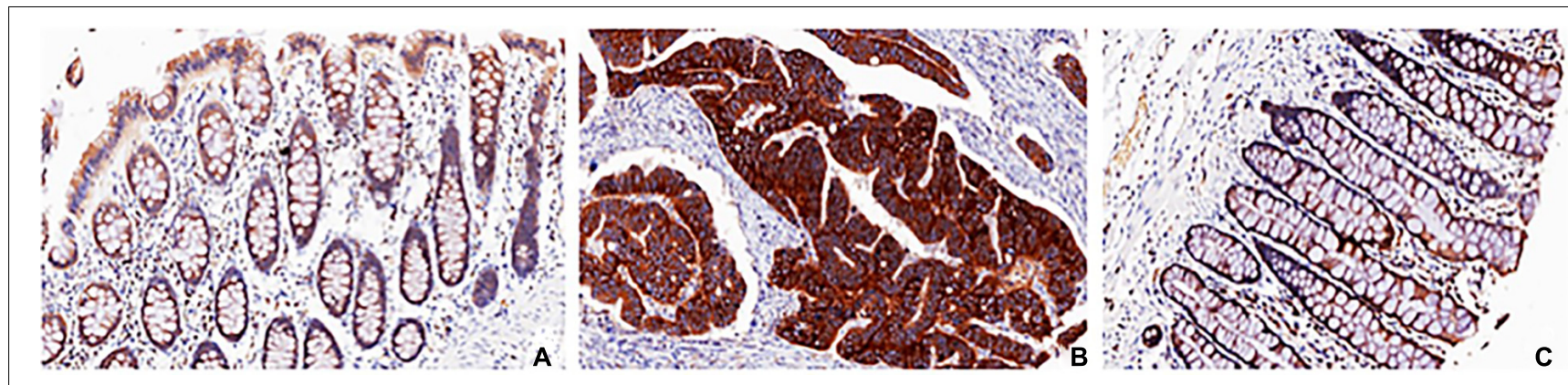

FIGURE 3 | Histochemistry of SLC7A1 in colorectal cancer and control. The pathological characteristics of colon adenocarcinoma (B) and adjacent normal colon tissue (C) in the tumor specimen were shown when sectioning and staining with anti-SLC7A1 antibody and compared with normal colon tissue from control (A).

levels, glucose and amino acids to modulate metabolic status and cellular responses. Overexpression of SLC38A9 or just its Regulator-binding domain activates mTORC1 signaling even in the absence of amino acids, while loss of SLC38A9 impairs mTORC1 activation by amino acids, particularly arginine (Wang et al., 2015). It has been demonstrated that amino acids regulated mTORC1 pathway through the Rag guanine triphosphatases (GTPases), which was regulated by a positive regulator GATOR2 and its interaction protein Sestrin2. Interestingly, leucine but not arginine, disrupts the Sestrin2-GATOR2 interaction and inhibits mTORC1 signaling (Saxton et al., 2016; Wolfson et al., 2016; Figure 1). In ASS1-deficient prostate cancer cells, arginine withdrawal leads to increased protein turnover via reduced synthesis and increased breakdown (suppression of mTOR and proteosomal degradation, respectively) and triggers caspasedependent and caspase-independent apoptotic cell death in a cell type- dependent manner (Changou et al., 2014; Szlosarek, 2014). Many cancer cell types use this autophagy-based mechanism to overcome the arginine supply problem.

\section{ARGININE METABOLISM AND STEM CELLS}

Arginine and its metabolism related molecules are closely related to stem cells and tumor stem cells. Recent studies have shown that arginine may be closely related to the physiological function of stem cells, including cancer stem cells. L-arginine can increase the expansion of small intestinal stem cells (ISCS) by targeting rapamycin complex1 and inhibiting Wnt2B secretion in small intestinal (SI) organoid models. In addition, L-arginine therapy can protect the intestinal tract from injury (Pearce et al., 2012). Zhang et al. found that exogenous L-arginine could promote the proliferation and intestinal epithelial renewal of ISCS, and protect the gut from the injury induced by TNF- $\alpha$ and 5-FU in mice (Hou et al., 2020). Arginine is also involved in the differentiation of human bone marrow mesenchymal stem cells into osteoblasts and adipocytes. Arginine significantly increased the expression of osteogenic transcription factors runt related transcription factor 2 (Runx2), dix5, and osterix in MSCs, and decreased adipocyte formation and triglyceride content. This effect is associated with the increased expression of Wnt $5 \mathrm{a}$ and nuclear factor of activated
T-cells (NFATc), which could be reversed by Wnt and NFATc antagonists (Huh et al., 2014).

It is also found that eNOS is involved in the differentiation of cancer stem cells. The expression of eNOS is increased in hyperproliferative intestinal crypts, which was associated with relapse free survival and overall survival. Overexpression of eNOS decrease the proliferation and expression of tumor stem cell markers such as Lgr5 and Vav3. These data suggest that eNOS may be a potential new target in mesenchymal colorectal tumors with poor prognosis (Penarando et al., 2018). Expression and activity of eNOS change dynamically in the process of differentiation of mouse adult pluripotent progenitor cells into endothelial cells induced by vascular endothelial growth factor. The expression and activity of eNOS increase on the 14th and 21st day of differentiation (Liu et al., 2007). The NO/NOS/sGC/PKGI pathway is also involved in the cardiac differentiation of embryonic stem cells (Spinelli et al., 2016). Further, neuronal NOS (nNOS) is involved in the differentiation of human induced pluripotent stem cells (hiPSCs). It is found that the expression of nNOS in migrating hiPSCs is down regulated by comparing the gene expression profiles of migrating and non-migrating hiPSCs, which is a related regulator of hiPSCs migration to cancer cells. Inhibiting activity of nNOS or down regulating its expression can reduce the migration of neural stem cells (NSCs) and improve their tumor tropism. This indicates that nNOS is a potential target for cancer therapy mediated by NSCs (Chen et al., 2013).

Besides arginine and NOS, arginine decarboxylase (ADC) is involved in the repair of MSCs against injury. It is found that overexpression of ADC can reduce the activation of Caspase-3, promote the phosphorylation of Akt and CREB, and increase the expression of BDNF in $\mathrm{H} 2 \mathrm{O} 2$ treated MSCs. These results indicate that $\mathrm{ADC}$ can protect MSCs against $\mathrm{H}_{2} \mathrm{O}_{2}$ toxicity and improve the survival rate of MSCs (Seo et al., 2013). $\mathrm{ADC}$ is also involved in the neuronal differentiation of neural progenitor cells (NPCs). NPCs overexpressing ADC gene can differentiate by neural lineage in vitro model of cerebral ischemia. Transplantation of NPCs over-expressing ADC can inhibit the volume of cerebral infarction, promote neural differentiation and protrusion in vivo. These results suggest that ADC has potential value in cell replacement therapy of ischemic stroke (Kim et al., 2019). 


\section{IMMUNE REGULATION OF ARGININE AND ITS METABOLITES IN CRC}

Arginine and its metabolites play an important role in the development of $\mathrm{T}$ cells and the maintenance of tumor microenvironment. Studies have found that arginine was very important for the formation of $\mathrm{T}$ cell receptor. Abnormal activation of Arg-1 could lead to the loss of arginine in the tumor environment, resulting in $\mathrm{T}$ cell dysplasia and the loss of tumor cell response related receptors (Rodriguez et al., 2003; Yachimovich-Cohen et al., 2010). In addition, arginine deficiency reduced the dephosphorylation level of cofilin protein and affected the recovery of actin in turn, which was necessary for the production of immune synapses and $\mathrm{T}$ cell proliferation (Feldmeyer et al., 2012). Furthermore, NO activated cyclooxygenase-2 (COX-2) and other inflammatory mediators, thereby creating a pro-oxidant microenvironment that supported cancer cell growth and suppressed antitumor immunity (Tham et al., 2014; Hugo et al., 2016). Besides, iNOS/NO positively regulated the production of $\mathrm{COX}-2$, microsomal prostaglandin $\mathrm{E}$ synthase-1 (mPGES1), and prostaglandin E2 (PGE2), which was related to immune-based anticancer therapies (Feun et al., 2008).

At present, the research concerning arginine and colorectal cancer immunity was very limited. Studies have found that myeloid suppressor cells (MDSCs) in colon cancer cells could inhibit the function of Th1/Th17/Th2 lymphocytes and form an immunosuppressive environment (Kang et al., 2010; Galon et al., 2013), which was crucial for the survival of tumor cells. MDSCs could be divided into M1 and M2 types according to cell morphology and polarization state. The activity of iNOS was significantly increased in M1 type, which has anti-tumor effect (Modolell et al., 1995; Allavena and Mantovani, 2012; Fridlender and Albelda, 2012). On the contrary, the upregulation of ARG1 level shows cancer promoting effect In M2 type (Fridlender et al., 2009; Ma et al., 2011). It was also shown that NO is required in pathogen-induced colon inflammation and immune cell infiltration, leading to dysplasia and colon cancer development (Erdman et al., 2009). In parallel, NO could activate macrophages and cytotoxic $\mathrm{T}$ cells, and augment the immune response against tumor cells (MacMicking et al., 1997; Marigo et al., 2016). Moreover, it has been demonstrated that macrophage-derived NO induced the expression of the adhesion molecule VCAM-1 in tumor vessels of melanoma xenografts, which is important for T-cell extravasation. Additionally, Nos2-/- macrophages could not co-transfer with CD8 + T cells yield T-cell homing to the tumor and tumor rejection (Sektioglu et al., 2016).

\section{MIRNAS AND LONG NON-CODING RNAS IN ARGININE METABOLISM AND CRC}

miRNAs are also involved in the regulation of arginine metabolism. miRNA can regulate arginine metabolism by regulating the expression of key molecules in arginine metabolism pathway, such as ASS (Bates et al., 2010; Tu et al., 2020), ARG1 (Bates et al., 2010; Yoo et al., 2019), ARG2 (Dunand-Sauthier et al., 2014; Jin et al., 2014; Kim et al., 2017; Wang Y. et al., 2017), CAT-1 (Chang et al., 2004; Li Y. et al., 2018), ODC (Jagannathan et al., 2015) and NOS (Perske et al., 2010; Yan et al., 2011; Guo et al., 2012; Sun et al., 2012; Zhu et al., 2013; Li et al., 2014, 2017, Li H.T. et al., 2018; Fu et al., 2015; Jiang et al., 2015; Zhang et al., 2015, 2020; Rasheed et al., 2016; Reilly et al., 2016; Muxel et al., 2017, 2018; Wang C. et al., 2017, Wang et al., 2019; Cui et al., 2020; Lin et al., 2020; Scalavino et al., 2020; Table 1). It has been found that multiple miRNAs could target the same enzyme or transporter protein, and the same molecule could also be regulated by multiple miRNAs. In addition, the regulatory mechanisms were diverse, which include binding to $3^{\prime}$-UTR region to degrade target genes by, inhibiting or increasing the expression of target genes or the enzyme activity at the same time. For example, microarray analysis of affinity purified RNAs and their validation identified CAT-1 as target gene of miR-122 (Bhattacharyya et al., 2006; Li et al., 2012), suggesting that arginine metabolism regulatory mechanisms are modulated by miRNA expression. Another example was the applying of ODC inhibitors to successfully reverse the LIN28/Let-7 axis and inhibit glycolytic metabolism in neuroblastoma (an entity similar to CRC in terms of arginine metabolism) (Lozier et al., 2015). Overexpression of ODC enhanced menin translation by reducing miR-29b, whereas polyamine depletion by inhibiting ODC increased miR-29b and suppressed menin expression (Ouyang et al., 2015). Since arginine metabolism is related to rectal cancer, searching the miRNAs targeted arginine metabolism-related enzyme may be new sights for the diagnosis and treatment of CRC.

Apart from argininemetabolism, specific microRNAs (miRNAs) have been identified in CRC. miRNAs are now known to be essential in malignancies, functioning as tumor suppressors and oncogenes (Kong et al., 2012). miRNAs can be used to diagnose the presence of CRC and help predict disease recurrence (Zhang et al., 2013). Differential expression of specific miRNAs sampled in tissues or plasma offers the prospect of their use in early detection and screening for colorectal cancer (Schetter et al., 2008; Ng et al., 2009; Liu et al., 2013; Luo et al., 2013; Toiyama et al., 2013; Chen et al., 2015; Table 2). miR-21, miR-92a, miR-29a, and miR-150 have strong potential as novel non-invasive biomarkers for early detection and prognosis of colorectal cancer (Huang et al., 2010; Ma et al., 2012; Wu et al., 2012). Analysis of colorectal tumors and adjacent non-neoplastic tissues from patients and colorectal cancer cell lines identified a group of 13 significantly altered miRNAs, including miR-31, miR-96, miR-133b, miR-135b, miR-145, and miR-183 (Bandres et al., 2006). Downregulation of the miR-143/145 cluster has been repeatedly reported in colorectal cancer (Ibrahim et al., 2011; Chivukula et al., 2014), allowing further CRC therapeutic investigations. A first cancer-targeted miRNA drug- MRX34, a liposome- based miR-34 mimic, entered Phase I clinical trials in patients with advanced hepatocellular carcinoma in 2013 (Ling et al., 2013). The immediately observed and promising advantage of using microRNA approaches is based on the ability 
TABLE 1 | miRNAs target to arginine metabolism.

\begin{tabular}{|c|c|c|c|c|}
\hline Study & Target & miRNA identified & Diseases or cells & Methods of analysis \\
\hline Tu et al. (2020) & ASS1 & miR-1291-5p & Pancreatic carcinoma & qRT-PCR \\
\hline Bates et al. (2010) & ASS1 & mmu-miRs-22, $-127,-470$, and -411 & Mice & qRT-PCR \\
\hline Bates et al. (2010) & ARG1 & mmu-miRs-29b, -676, -382, and -669b & Mice & qRT-PCR \\
\hline Yoo et al. (2019) & ARG1 & miR-340-5p & Peripheral Blood Cells & Luciferase reporter assay \\
\hline Wang Y. et al. (2017) & ARG2 & miR-613 & HCMV-positive glioblastoma & Luciferase reporter assay \\
\hline Jin et al. (2014) & ARG2 & $\operatorname{miR}-17-5 p$ & Human pulmonary artery smooth muscle cell & qRT-PCR \\
\hline Kim et al. (2017) & ARG2 & miR-1299 & Melasma & Luciferase reporter assay \\
\hline Dunand-Sauthier et al. (2014) & ARG2 & miR-155 & T cell & Luciferase reporter assay \\
\hline Li Y. et al. (2018) & CAT-1 & miR-122 & Isoniazid-induced liver injury & qRT-PCR \\
\hline Chang et al. (2004) & CAT-1 & miR-122 & Primary human hepatocytes & Luciferase reporter assay \\
\hline Jagannathan et al. (2015) & ODC & miR-29b & Myeloma cells & qRT-PCR \\
\hline Wang C. et al. (2017) & eNOS & miR-138 and miR-199a & Rats & Luciferase reporter assay \\
\hline Zhang et al. (2020) & eNOS & $\operatorname{miR}-221$ & Atherosclerosis & qRT-PCR \\
\hline Wang et al. (2019) & eNOS & $m i R-155-5 p$ and miR-24-3p & Atrial fibrillation & qRT-PCR \\
\hline Li et al. (2017) & eNOS & miR-455-3p & HUVECS & qRT-PCR \\
\hline Fu et al. (2015) & eNOS & miR-335 and miR-543 & Prostate cancer & Luciferase reporter assay \\
\hline Jiang et al. (2015) & eNOS & miR-584 and miR-335 & Severe preeclampsia & Luceriferase assay \\
\hline Yan et al. (2011) & eNOS & 27-nt miRNA & Endothelial cell & qRT-PCR \\
\hline Li et al. (2014) & eNOS & $\mathrm{miR}-155$ & Severe preeclampsia, HTR-8/SVneo cells & qRT-PCR \\
\hline Zhang et al. (2015) & eNOS & $\mathrm{miR}-155$ & Human aortic SMCs (HASMCs) & Luciferase reporter assay \\
\hline Sun et al. (2012) & eNOS & $\operatorname{miR}-155$ & Human umbilical vein endothelial cell & Luciferase reporter assay \\
\hline Li H.T. et al. (2018) & eNOS & $\operatorname{miR}-24$ & Subarachnoid hemorrhage (SAH) & Luciferase reporter assay \\
\hline Muxel et al. (2018) & iNOS & let-7e & Lamazonensis-infected & qRT-PCR \\
\hline Scalavino et al. (2020) & iNOS & miR-369-3p & Inflammatory dendritic cells & qRT-PCR \\
\hline Lin et al. (2020) & iNOS & miR-206-3p and miR-381-3p & Macrophages & qRT-PCR \\
\hline Cui et al. (2020) & iNOS & miR-302b-5p & Parkinson's disease & Luciferase reporter assay \\
\hline Perske et al. (2010) & iNOS & $\mathrm{miR}-146 \mathrm{a}$ & Mouse renal cell carcinoma cell line & qRT-PCR \\
\hline Guo et al. (2012) & iNOS & miR-939 & Human hepatocytes & Luciferase reporter assay \\
\hline Zhu et al. (2013) & iNOS & $\mathrm{miR}-26 \mathrm{a}$ & NPM-ALK(+) T-cell lymphoma & Luciferase reporter assay \\
\hline Rasheed et al. (2016) & iNOS & miR-26a-5p & Human osteoarthritis chondrocytes & Luciferase reporter assay \\
\hline Reilly et al. (2016) & nNOS & miR-31 & Human atrial fibrillation & qRT-PCR \\
\hline Muxel et al. (2017) & NOS2 & miR-294 and miR-721 & Lamazonensis-infected & qRT-PCR \\
\hline
\end{tabular}

to concurrently target multiple effectors of pathways involved in cell differentiation, proliferation and survival, as opposed to targeting a single enzyme or transporter of the arginine metabolic network (which involve over $10 \mathrm{key}$ enzymes and 2 critical transporters). However, there was little direct evidence that miRNAs affect the occurrence and development of CRC by regulating arginine metabolism. Since arginine metabolism is related to rectal cancer, searching the miRNAs targeted arginine metabolism-related enzyme may be new sights for the diagnosis and treatment of CRC.

Long non-coding RNAs (lncRNAs) are the second most commonly studied ncRNAs in colorectal cancer, with increasing evidence of their implications in CRC specific gene expression and miRNAs. LncRNAs can act as miRNAs sponges and affect translation efficacy (Guttman and Rinn, 2012). Aberrant lncRNAs may have a functional role in the pathogenesis of colorectal cancer and clinical implications, such as HOTARI and MALAT1 (Gupta et al., 2010; Okugawa et al., 2015). Detecting interaction networks and causal relationships between the dysregulation of miRNAs/lncRNAs and hyperactivity of arginine metabolism will be offer insights into novel strategies for secondary prevention and treatment of colorectal cancer.

\section{SPECIFIC TARGETING OF ARGININE METABOLISM IN COLORECTAL CANCER TREATMENT}

Based on previously mentioned, hyperactive arginine metabolism play important roles in CRC development and development. Therefore, it is hopeful to inhibit this pathway for therapeutic purposes. For instance, drugs for ODC inhibition and SSAT induction have been used for cancer therapy. Nevertheless, the long-term efficacy needs further study.

The use of arginine deaminase (ADI) and arginine deprivation to inhibit tumor growth has made important progress, and many clinical trials are in progress, including in liver cancer, sarcoma and lymphoma 
TABLE 2 | Circulating miRNAs changes associated with colorectal cancer.

\begin{tabular}{|c|c|c|c|c|c|c|c|}
\hline \multirow[t]{2}{*}{ Study } & \multicolumn{2}{|c|}{ Sample size } & \multirow[t]{2}{*}{ Source } & \multirow[t]{2}{*}{ Method of analysis } & \multirow[t]{2}{*}{ miRNA identified } & \multirow[t]{2}{*}{ Normalizer } & \multirow[t]{2}{*}{ Observations } \\
\hline & \multicolumn{2}{|c|}{ Patients controls } & & & & & \\
\hline Ng et al. (2009) & 120 & 90 & Plasma & $\begin{array}{l}\text { Microarray profiling and } \\
\text { Validation by qPCR }\end{array}$ & $\begin{array}{l}\text { miR-17-3p, miR-92, } \\
\text { miR-95, miR-135b, } \\
\text { miR-222, etc. }\end{array}$ & RNU6B & $\begin{array}{l}\text { First study to evaluate } \\
\text { circulating miRNA in CRC }\end{array}$ \\
\hline Huang et al. (2010) & 120 & 79 & Plasma & $\begin{array}{l}\text { qPCR on specific } \\
\text { miRNAs }\end{array}$ & miR-29a, miR-92a & miR-16 & $\begin{array}{l}\text { Non-invasive biomarkers for } \\
\text { early detection of CRC }\end{array}$ \\
\hline Pu et al. (2010) & 103 & 37 & Plasma & $\begin{array}{l}\text { qPCR on specific } \\
\text { miRNAs }\end{array}$ & miR-221 & $\mathrm{N} / \mathrm{A}$ & $\begin{array}{l}86 \% \text { sensitivity and } 41 \% \\
\text { specificity in CRC }\end{array}$ \\
\hline Liu et al. (2013) & 200 & 80 & Serum & $\begin{array}{l}\text { qPCR on specific } \\
\text { miRNAs }\end{array}$ & miR-21 and miR-92a & miR-16 & $\begin{array}{l}\text { Both miRNAs have potential } \\
\text { value for early detection }\end{array}$ \\
\hline Kanaan et al. (2012) & 30 & 30 & Plasma & $\begin{array}{l}\text { Microarray profiling and } \\
\text { Validation by qPCR }\end{array}$ & $\operatorname{miR}-21$ & U6 & $\begin{array}{l}\text { miR-21 differentiated CRC with } \\
\text { 90\% specificity and sensitivity }\end{array}$ \\
\hline Zhang et al. (2013) & 78 & 86 & Plasma & $\begin{array}{l}\text { qPCR on specific } \\
\text { miRNAs }\end{array}$ & miR-18 and miR-200c & RNU6B & $\begin{array}{l}84.6 \% \text { sensitivity and } 75.6 \% \\
\text { specificity in CRC }\end{array}$ \\
\hline Luo et al. (2013) & 130 & 244 & Plasma & $\begin{array}{l}\text { Microarray profiling and } \\
\text { Validation by qPCR }\end{array}$ & $\begin{array}{l}\text { miR-18a, miR-20a, } \\
\text { miR-21, miR-29a, } \\
\text { miR-92a, miR-106b, } \\
\text { miR-133a, miR-143, } \\
\text { miR-145 }\end{array}$ & miR-16 & $\begin{array}{l}\text { Potential use in a multi-marker } \\
\text { blood based test for early } \\
\text { detection of CRC }\end{array}$ \\
\hline Toiyama et al. (2013) & 198 & 65 & Serum & $\begin{array}{l}\text { qPCR on specific } \\
\text { miRNAs }\end{array}$ & miR-21 & cel-miR-39 & $\begin{array}{l}92 \% \text { sensitivity and } 81 \% \\
\text { specificity in CRC }\end{array}$ \\
\hline Wang et al. (2014) & 113 & 89 & Serum & $\begin{array}{l}\text { qPCR on specific } \\
\text { miRNAs }\end{array}$ & $\begin{array}{l}\text { miR-21, miR-31, } \\
\text { miR-92a, miR-181b, } \\
\text { miR-203, let-7g }\end{array}$ & miR-16 & $\begin{array}{l}\text { Non-invasive biomarkers for } \\
\text { early detection of CRC }\end{array}$ \\
\hline Zanutto et al. (2014) & 29 & 29 & Plasma & $\begin{array}{l}\text { qPCR on specific } \\
\text { miRNAs }\end{array}$ & miR-21 and miR-378 & miR-16 & $\begin{array}{l}\text { miR-378 discriminates CRC } \\
\text { from healthy individuals }\end{array}$ \\
\hline Du et al. (2014) & 49 & 49 & Plasma & $\begin{array}{l}\text { qPCR on specific } \\
\text { miRNAs }\end{array}$ & miR-21 and miR-92a & cel-miR-39 & $\begin{array}{l}\text { miR-21 had a higher diagnostic } \\
\text { efficiency than miR-92a }\end{array}$ \\
\hline Ogata-Kawata et al. (2014) & 88 & 11 & $\begin{array}{c}\text { Serum } \\
\text { (Exosome) }\end{array}$ & $\begin{array}{l}\text { Microarray profiling and } \\
\text { Validation by qPCR }\end{array}$ & $\begin{array}{l}\text { miR-21, let-7a, miR-23a, } \\
\text { miR- 150, miR-223, } \\
\text { miR-1229, miR-1246 }\end{array}$ & $\operatorname{miR}-451$ & $\begin{array}{l}\text { First study to serum exosomal } \\
\text { miRNAs in CRC }\end{array}$ \\
\hline Basati et al. (2014) & 40 & 40 & Serum & $\begin{array}{l}\text { qPCR on specific } \\
\text { miRNAs }\end{array}$ & miR-21 & RNU6B & $\begin{array}{l}77 \% \text { sensitivity and } 78 \% \\
\text { specificity in CRC }\end{array}$ \\
\hline Lv et al. (2015) & 146 & 60 & Serum & $\begin{array}{l}\text { qPCR on specific } \\
\text { miRNAs }\end{array}$ & miR-155 & N/A & Upregulated in CRC \\
\hline Chen et al. (2015) & 100 & 79 & Plasma & $\begin{array}{l}\text { qPCR on specific } \\
\text { miRNAs }\end{array}$ & miR-20a and miR-106a & miR-16 & $\begin{array}{l}\text { miR-20a: } 46 \% \text { sensitivity and } \\
\text { 73\% specificity; miR-106a: } 74 \\
\text { and } 44 \% \text {, respectively }\end{array}$ \\
\hline Fang et al. (2015) & 111 & 130 & Plasma & $\begin{array}{l}\text { qPCR on specific } \\
\text { miRNAs }\end{array}$ & $\begin{array}{l}\text { miR-24, miR-320a, } \\
\text { miR-423-5p }\end{array}$ & cel-miR-39 & $\begin{array}{l}\text { Sensitivity: miR-24: 78\%; } \\
\text { miR-320a: 91\%; miR-423: 89\% }\end{array}$ \\
\hline
\end{tabular}

(Phillips et al., 2013). However, it has to be emphasized that for various reasons this strategy cannot be very promising for CRC. In vitro experiments It have been shown that the intracellular arginine synthesis enzyme ASS is defective in many cancer, including renal cell carcinoma, HCC and so on, so that their growth is dependent on external arginine supplementation (Cheng et al., 2007; Kim et al., 2009; Delage et al., 2010) or intracellular synthesis with ASS and ASL. Thus, arginine deprivation (potentially also combined with ASL downregulation) is only a viable option for cancers with defects in these enzymes.

Nevertheless, there is nevertheless a positive outlook in arginine-targeting in CRC. L-arginine is an important material for protein synthesis for human, and play important roles for all kind of cells (Rodriguez et al., 2007; Norian et al., 2009; Wu et al., 2009; Morris, 2010). Tumor-infiltrating immune cells cannot effectively uptake L-arginine in the tumor tissues (Rodriguez et al., 2007; Norian et al., 2009), thus, significantly increased L-arginine and L-Citrulline concentrations were found in CRC tissues (Mao et al., 2010). This indicated that L-arginine bioavailability is higher in the CRC tissue. In addition, ASS and ASL38 are high expression in colorectal cancer cells. Thus, arginine deprivation was rather expected to decrease the effectiveness of tumor-infiltrating cells, therefore, its function is limited on cancer cells. However, clinical data confirmed that L-arginine successfully improved cancer patient immunity, thus demonstrated a benefit of L-arginine as a supplement to the treatment of colorectal cancer (Ma et al., 2007). As such, we supposed that inhibiting arginine uptake by specifically targeting arginine transporters may be better for CRC than a systemic arginine deprivation. Studies on specific interventions in related regulatory mechanisms of L-arginine transport pathways and the 
innate compensation of each arginine transporter in CRC cells are ongoing in our team.

\section{CONCLUSION}

Colorectal cancer is one of the common malignant tumors, but the curative effect of metastatic colorectal cancer is poor. With the deepening of research, more and more evidence shows that arginine metabolism is closely related to the occurrence and development of colorectal cancer. As polyamines are the most important metabolite of arginine, metabonomics analysis may be used in the diagnosis and screening of colorectal cancer in the future. In addition, arginine deprivation may be a viable option for cancer treatment, although further clinical trials are needed to confirm it. Because blocking arginine transporter can inhibit the uptake of arginine and inhibit the growth of tumor, blocking arginine transporter may be another potential anticancer strategy. Finally, more studies are needed to fully elucidate the regulatory role of arginine metabolism cycle in colorectal cancer.

miRNAs have been established as critical plays in colorectal cancer pathogenesis, early detection and prognosis. The advantage of using microRNA-based therapeutic is based on its ability to concurrently target multiple effectors of pathways involved in cancer cell differentiation, proliferation and survival, and arginine metabolism pathways. Therefore, applying one

\section{REFERENCES}

Alexandrou, C., Al-Aqbi, S. S., Higgins, J. A., Boyle, W., Karmokar, A., Andreadi, C., et al. (2018). Sensitivity of colorectal cancer to arginine deprivation therapy is shaped by differential expression of urea cycle enzymes. Sci. Rep. 8:12096. doi: 10.1038/s41598-018-30591-7

Allavena, P., and Mantovani, A. (2012). Immunology in the clinic review series; focus on cancer: tumour-associated macrophages: undisputed stars of the inflammatory tumour microenvironment. Clin. Exp. Immunol. 167, 195-205. doi: 10.1111/j.1365-2249.2011.04515.x

Altun, A., Temiz, T. K., Balci, E., Polat, Z. A., and Turan, M. (2013). Effects of tyrosine kinase inhibitor E7080 and eNOS inhibitor L-NIO on colorectal cancer alone and in combination. Chinese J. Cancer Res. 25, 572-584. doi: 10.3978/j. issn.1000-9604.2013.10.10

Ariel, I., Hochberg, A., and Shochina, M. (1998). Endothelial nitric oxide synthase immunoreactivity in early gestation and in trophoblastic disease. J. Clin. Pathol. 51, 427-431. doi: 10.1136/jcp.51.6.427

Bandres, E., Cubedo, E., Agirre, X., Malumbres, R., Zarate, R., Ramirez, N., et al. (2006). Identification by Real-time PCR of 13 mature microRNAs differentially expressed in colorectal cancer and non-tumoral tissues. Mol. Cancer 5:29. doi: 10.1186/1476-4598-5-29

Basati, G., Emami Razavi, A., Abdi, S., and Mirzaei, A. (2014). Elevated level of microRNA-21 in the serum of patients with colorectal cancer. Med. Oncol. 31:205. doi: 10.1007/s12032-014-0205-3

Bates, D. J., Li, N., Liang, R., Sarojini, H., An, J., Masternak, M. M., et al. (2010). MicroRNA regulation in Ames dwarf mouse liver may contribute to delayed aging. Aging Cell 9, 1-18. doi: 10.1111/j.1474-9726.2009.00529.x

Battaglia, V., DeStefano Shields, C., Murray-Stewart, T., and Casero, R. A. Jr. (2014). Polyamine catabolism in carcinogenesis: potential targets for chemotherapy and chemoprevention. Amino Acids 46, 511-519. doi: 10.1007/ s00726-013-1529-6

Bhattacharyya, S. N., Habermacher, R., Martine, U., Closs, E. I., and Filipowicz, W. (2006). Relief of microRNA-mediated translational repression in human cells subjected to stress. Cell 125, 1111-1124. doi: 10.1016/j.cell.2006.04.031 or two miRNAs cocktail targeting more than two enzymes or arginine transporters, such as targeting CAT-1 and ASS, should be expected more efficient in the treatment of colorectal cancer.

\section{AUTHOR CONTRIBUTIONS}

TD and JH wrote the manuscript. TD collected the data. JH reviewed and revised the manuscript. Both authors contributed to the article and approved the submitted version.

\section{FUNDING}

This study was supported by the Technology Development Project of Pudong Science, Technology and Economic Commission of Shanghai (No. PKJ2017-Y17), the Key Specialty Construction Project of Pudong Health and Family Planning Commission of Shanghai (No. PWZzk2017-26), the National Natural Science Foundation of China (No. 81871953), and the Jiangxi Youth Science Fund (No. 20171BAB215043).

\section{ACKNOWLEDGMENTS}

We thank Ewelina Biskup for excellent assistance in the performance of this manuscript.

Brenner, H., Kloor, M., and Pox, C. P. (2014). Colorectal cancer. Lancet 383, 1490-1502. doi: 10.1016/S0140-6736(13)61649-9

Camps, J., Pitt, J. J., Emons, G., Hummon, A. B., Case, C. M., Grade, M., et al. (2013). Genetic amplification of the NOTCH modulator LNX2 upregulates the WNT/beta-catenin pathway in colorectal cancer. Cancer Res. 73, 2003-2013. doi: 10.1158/0008-5472.CAN-12-3159

Center, M. M., Jemal, A., Smith, R. A., and Ward, E. (2009a). Worldwide variations in colorectal cancer. CA Cancer J. Clin. 59, 366-378. doi: 10.3322/caac.20038

Center, M. M., Jemal, A., and Ward, E. (2009b). International trends in colorectal cancer incidence rates. Cancer Epidemiol. Biomarkers Prevent. 18, 1688-1694. doi: 10.1158/1055-9965.EPI-09-0090

Chang, J., Nicolas, E., Marks, D., Sander, C., Lerro, A., Buendia, M. A., et al. (2004). miR-122, a mammalian liver-specific microRNA, is processed from hcr mRNA and may downregulate the high affinity cationic amino acid transporter CAT-1. RNA Biol. 1, 106-113. doi: 10.4161/rna.1.2.1066

Changou, C. A., Chen, Y. R., Xing, L., Yen, Y., Chuang, F. Y., Cheng, R. H., et al. (2014). Arginine starvation-associated atypical cellular death involves mitochondrial dysfunction, nuclear DNA leakage, and chromatin autophagy. Proc. Natl. Acad. Sci. U.S.A. 111, 14147-14152. doi: 10.1073/pnas.140417 1111

Chen, C., Wang, Y., Goh, S. S., Yang, J., Lam, D. H., Choudhury, Y., et al. (2013). Inhibition of neuronal nitric oxide synthase activity promotes migration of human-induced pluripotent stem cell-derived neural stem cells toward cancer cells. J. Neurochem. 126, 318-330. doi: 10.1111/jnc.12199

Chen, W. Y., Zhao, X. J., Yu, Z. F., Hu, F. L., Liu, Y. P., Cui, B. B., et al. (2015). The potential of plasma miRNAs for diagnosis and risk estimation of colorectal cancer. Int. J. Clin. Exp. Pathol. 8, 7092-7101.

Cheng, P. N., Lam, T. L., Lam, W. M., Tsui, S. M., Cheng, A. W., Lo, W. H., et al. (2007). Pegylated recombinant human arginase (rhArg-peg5,000mw) inhibits the in vitro and in vivo proliferation of human hepatocellular carcinoma through arginine depletion. Cancer Res. 67, 309-317. doi: 10.1158/0008-5472. CAN-06-1945

Chhatwal, V. J., Ngoi, S. S., Chan, S. T., Chia, Y. W., and Moochhala, S. M. (1994). Aberrant expression of nitric oxide synthase in human polyps, neoplastic 
colonic mucosa and surrounding peritumoral normal mucosa. Carcinogenesis 15, 2081-2085. doi: 10.1093/carcin/15.10.2081

Chivukula, R. R., Shi, G., Acharya, A., Mills, E. W., Zeitels, L. R., Anandam, J. L., et al. (2014). An essential mesenchymal function for miR-143/145 in intestinal epithelial regeneration. Cell 157, 1104-1116. doi: 10.1016/j.cell.2014.03.055

Closs, E. I., Boissel, J. P., Habermeier, A., and Rotmann, A. (2006). Structure and function of cationic amino acid transporters (CATs). J. Membr. Biol. 213, 67-77. doi: 10.1007/s00232-006-0875-7

Cui, X., Li, M., He, Z., Hu, L., Liu, J., Yan, J., et al. (2020). MiR-302b-5p enhances the neuroprotective effect of IGF-1 in methyl-4-phenyl-1,2,3,6-tetrahydropyridineinduced Parkinson's disease by regulating inducible nitric-oxide synthase. Cell Biochem. Funct. 38, 1025-1035. doi: 10.1002/cbf.3534

Cunningham, D., Atkin, W., Lenz, H. J., Lynch, H. T., Minsky, B., Nordlinger, B., et al. (2010). Colorectal cancer. Lancet 375, 1030-1047. doi: 10.1016/S01406736(10)60353-4

De Sousa, E. M. F., Wang, X., Jansen, M., Fessler, E., Trinh, A., de Rooij, L. P., et al. (2013). Poor-prognosis colon cancer is defined by a molecularly distinct subtype and develops from serrated precursor lesions. Nat. Med. 19, 614-618. doi: $10.1038 / \mathrm{nm} .3174$

Delage, B., Fennell, D. A., Nicholson, L., McNeish, I., Lemoine, N. R., Crook, T., et al. (2010). Arginine deprivation and argininosuccinate synthetase expression in the treatment of cancer. Int. J. Cancer 126, 2762-2772. doi: 10.1002/ijc. 25202

Du, M., Liu, S., Gu, D., Wang, Q., Zhu, L., Kang, M., et al. (2014). Clinical potential role of circulating microRNAs in early diagnosis of colorectal cancer patients. Carcinogenesis 35, 2723-2730. doi: 10.1093/carcin/bgu189

Dunand-Sauthier, I., Irla, M., Carnesecchi, S., Seguin-Estevez, Q., Vejnar, C. E., Zdobnov, E. M., et al. (2014). Repression of arginase-2 expression in dendritic cells by microRNA-155 is critical for promoting T cell proliferation. J. Immunol. 193, 1690-1700. doi: 10.4049/jimmunol.1301913

Ensor, C. M., Holtsberg, F. W., Bomalaski, J. S., and Clark, M. A. (2002). Pegylated arginine deiminase (ADI-SS PEG20,000 mw) inhibits human melanomas and hepatocellular carcinomas in vitro and in vivo. Cancer Res. 62, 5443-5450.

Erdman, S. E., Rao, V. P., Poutahidis, T., Rogers, A. B., Taylor, C. L., Jackson, E. A., et al. (2009). Nitric oxide and TNF-alpha trigger colonic inflammation and carcinogenesis in Helicobacter hepaticus-infected, Rag2-deficient mice. Proc. Natl. Acad. Sci. U.S.A. 106, 1027-1032. doi: 10.1073/pnas.0812347106

Evageliou, N. F., and Hogarty, M. D. (2009). Disrupting polyamine homeostasis as a therapeutic strategy for neuroblastoma. Clin. Cancer Res. 15, 5956-5961. doi: 10.1158/1078-0432.CCR-08-3213

Fang, Z., Tang, J., Bai, Y., Lin, H., You, H., Jin, H., et al. (2015). Plasma levels of microRNA-24, microRNA-320a, and microRNA-423-5p are potential biomarkers for colorectal carcinoma. J. Exp. Clin. Cancer. Res. 34:86. doi: 10. 1186/s13046-015-0198-6

Feldmeyer, N., Wabnitz, G., Leicht, S., Luckner-Minden, C., Schiller, M., Franz, T., et al. (2012). Arginine deficiency leads to impaired cofilin dephosphorylation in activated human T lymphocytes. Int. Immunol. 24, 303-313. doi: 10.1093/ intimm/dxs004

Feun, L., You, M., Wu, C. J., Kuo, M. T., Wangpaichitr, M., Spector, S., et al. (2008). Arginine deprivation as a targeted therapy for cancer. Curr. Pharm. Des. 14, 1049-1057. doi: 10.2174/138161208784246199

Fridlender, Z. G., and Albelda, S. M. (2012). Tumor-associated neutrophils: friend or foe? Carcinogenesis 33, 949-955. doi: 10.1093/carcin/bgs123

Fridlender, Z. G., Sun, J., Kim, S., Kapoor, V., Cheng, G., Ling, L., et al. (2009). Polarization of tumor-associated neutrophil phenotype by TGF-beta: "N1" versus "N2" TAN. Cancer Cell 16, 183-194. doi: 10.1016/j.ccr.2009.06.017

Fu, Q., Liu, X., Liu, Y., Yang, J., Lv, G., and Dong, S. (2015). MicroRNA-335 and -543 suppress bone metastasis in prostate cancer via targeting endothelial nitric oxide synthase. Int. J. Mol. Med. 36, 1417-1425. doi: 10.3892/ijmm.2015.2355

Fukumura, D., Kashiwagi, S., and Jain, R. K. (2006). The role of nitric oxide in tumour progression. Nat. Rev. Cancer 6, 521-534. doi: 10.1038/nrc1910

Galon, J., Angell, H. K., Bedognetti, D., and Marincola, F. M. (2013). The continuum of cancer immunosurveillance: prognostic, predictive, and mechanistic signatures. Immunity 39, 11-26. doi: 10.1016/j.immuni.2013. 07.008

Gerner, E. W., and Meyskens, F. L. Jr. (2004). Polyamines and cancer: old molecules, new understanding. Nat. Rev. Cancer 4, 781-792. doi: 10.1038/ $\operatorname{nrc1454}$
Gerner, E. W., and Meyskens, F. L. Jr. (2009). Combination chemoprevention for colon cancer targeting polyamine synthesis and inflammation. Clin. Cancer Res. 15, 758-761. doi: 10.1158/1078-0432.CCR-08-2235

Goodwin, A. C., Destefano Shields, C. E., Wu, S., Huso, D. L., Wu, X., Murray-Stewart, T. R., et al. (2011). Polyamine catabolism contributes to enterotoxigenic Bacteroides fragilis-induced colon tumorigenesis. Proc. Natl. Acad. Sci. U.S.A. 108, 15354-15359. doi: 10.1073/pnas.1010203108

Guo, Z., Shao, L., Zheng, L., Du, Q., Li, P., John, B., et al. (2012). miRNA939 regulates human inducible nitric oxide synthase posttranscriptional gene expression in human hepatocytes. Proc. Natl. Acad. Sci. U.S.A. 109, 5826-5831. doi: $10.1073 /$ pnas.1118118109

Gupta, N., Miyauchi, S., Martindale, R. G., Herdman, A. V., Podolsky, R., Miyake, K., et al. (2005). Upregulation of the amino acid transporter ATB0,+ (SLC6A14) in colorectal cancer and metastasis in humans. Biochim. Biophys. Acta 1741, 215-223. doi: 10.1016/j.bbadis.2005.04.002

Gupta, R. A., Shah, N., Wang, K. C., Kim, J., Horlings, H. M., Wong, D. J., et al. (2010). Long non-coding RNA HOTAIR reprograms chromatin state to promote cancer metastasis. Nature 464, 1071-1076. doi: 10.1038/nature08975

Guttman, M., and Rinn, J. L. (2012). Modular regulatory principles of large non-coding RNAs. Nature 482, 339-346. doi: 10.1038/nature10887

Hou, Q., Dong, Y., Yu, Q., Wang, B., Le, S., Guo, Y., et al. (2020). Regulation of the Paneth cell niche by exogenous L-arginine couples the intestinal stem cell function. FASEB J. 34, 10299-10315. doi: 10.1096/fj.201902573RR

Huang, H. L., Chen, W. C., Hsu, H. P., Cho, C. Y., Hung, Y. H., Wang, C. Y., et al. (2015). Argininosuccinate lyase is a potential therapeutic target in breast cancer. Oncol. Rep. 34, 3131-3139. doi: 10.3892/or.2015.4280

Huang, H. L., Chen, W. C., Hsu, H. P., Cho, C. Y., Hung, Y. H., Wang, C. Y., et al. (2017). Silencing of argininosuccinate lyase inhibits colorectal cancer formation. Oncol. Rep. 37, 163-170. doi: 10.3892/or.2016.5221

Huang, Z., Huang, D., Ni, S., Peng, Z., Sheng, W., and Du, X. (2010). Plasma microRNAs are promising novel biomarkers for early detection of colorectal cancer. Int. J. Cancer 127, 118-126. doi: 10.1002/ijc.25007

Hugo, W., Zaretsky, J. M., Sun, L., Song, C., Moreno, B. H., Hu-Lieskovan, S., et al. (2016). Genomic and transcriptomic features of response to anti-PD-1 therapy in metastatic melanoma. Cell 165, 35-44. doi: 10.1016/j.cell.2016.02.065

Huh, J. E., Choi, J. Y., Shin, Y. O., Park, D. S., Kang, J. W., Nam, D., et al. (2014). Arginine enhances osteoblastogenesis and inhibits adipogenesis through the regulation of Wnt and NFATc signaling in human mesenchymal stem cells. Int. J. Mol. Sci. 15, 13010-13029. doi: 10.3390/ijms 150713010

Ibrahim, A. F., Weirauch, U., Thomas, M., Grunweller, A., Hartmann, R. K., and Aigner, A. (2011). MicroRNA replacement therapy for miR-145 and miR33a is efficacious in a model of colon carcinoma. Cancer Res. 71, 5214-5224. doi: 10.1158/0008-5472.CAN-10-4645

Jagannathan, S., Vad, N., Vallabhapurapu, S., Anderson, K. C., and Driscoll, J. J. (2015). MiR-29b replacement inhibits proteasomes and disrupts aggresome+autophagosome formation to enhance the antimyeloma benefit of bortezomib. Leukemia 29, 727-738. doi: 10.1038/leu.2014.279

Jahani, M., Azadbakht, M., Norooznezhad, F., and Mansouri, K. (2017). 1arginine alters the effect of 5-fluorouracil on breast cancer cells in favor of apoptosis. Biomed. Pharmacother. 88, 114-123. doi: 10.1016/j.biopha.2017. 01.047

Jiang, F., Li, J., Wu, G., Miao, Z., Lu, L., Ren, G., et al. (2015). Upregulation of microRNA335 and microRNA584 contributes to the pathogenesis of severe preeclampsia through downregulation of endothelial nitric oxide synthase. Mol. Med. Rep. 12, 5383-5390. doi: 10.3892/mmr.2015.4018

Jin, Y., Chen, B., Tipple, T. E., and Nelin, L. D. (2014). Arginase II is a target of miR-17-5p and regulates miR-17-5p expression in human pulmonary artery smooth muscle cells. Am. J. Physiol. Lung. Cell Mol. Physiol. 307, L197-L204. doi: 10.1152/ajplung.00266.2013

Jung, J., Genau, H. M., and Behrends, C. (2015). Amino acid-dependent mTORC1 regulation by the lysosomal membrane protein SLC38A9. Mol. Cell. Biol. 35, 2479-2494. doi: 10.1128/MCB.00125-15

Kanaan, Z., Rai, S. N., Eichenberger, M. R., Roberts, H., Keskey, B., Pan, J., et al. (2012). Plasma miR-21: a potential diagnostic marker of colorectal cancer. Ann. Surg. 256, 544-551. doi: 10.1097/SLA.0b013e318265bd6f

Kang, J. C., Chen, J. S., Lee, C. H., Chang, J. J., and Shieh, Y. S. (2010). Intratumoral macrophage counts correlate with tumor progression in colorectal cancer. J. Surg. Oncol. 102, 242-248. doi: 10.1002/jso.21617 
Karunakaran, S., Ramachandran, S., Coothankandaswamy, V., Elangovan, S., Babu, E., Periyasamy-Thandavan, S., et al. (2011). SLC6A14 (ATB0,+) protein, a highly concentrative and broad specific amino acid transporter, is a novel and effective drug target for treatment of estrogen receptor-positive breast cancer. J. Biol. Chem. 286, 31830-31838. doi: 10.1074/jbc.M111.229518

Kim, J. Y., Kim, J. H., Jung, H., Lee, W. T., and Lee, J. E. (2019). Restorative mechanism of neural progenitor cells overexpressing arginine decarboxylase genes following ischemic injury. Exp. Neurobiol. 28, 85-103. doi: 10.5607/en. 2019.28.1.85

Kim, N. H., Choi, S. H., Yi, N., Lee, T. R., and Lee, A. Y. (2017). Arginase-2, a miR-1299 target, enhances pigmentation in melasma by reducing melanosome degradation via senescence-induced autophagy inhibition. Pigment Cell Melanoma Res. 30, 521-530. doi: 10.1111/pcmr.12605

Kim, R. H., Coates, J. M., Bowles, T. L., McNerney, G. P., Sutcliffe, J., Jung, J. U., et al. (2009). Arginine deiminase as a novel therapy for prostate cancer induces autophagy and caspase-independent apoptosis. Cancer Res. 69, 700-708. doi: 10.1158/0008-5472.CAN-08-3157

Kong, Y. W., Ferland-McCollough, D., Jackson, T. J., and Bushell, M. (2012). microRNAs in cancer management. Lancet Oncol. 13, e249-e258. doi: 10.1016/ S1470-2045(12)70073-6

LaMuraglia, G. M., Lacaine, F., and Malt, R. A. (1986). High ornithine decarboxylase activity and polyamine levels in human colorectal neoplasia. Ann. Surg. 204, 89-93. doi: 10.1097/00000658-198607000-00013

Laplante, M., and Sabatini, D. M. (2012). mTOR signaling in growth control and disease. Cell 149, 274-293. doi: 10.1016/j.cell.2012.03.017

Li, H. T., Wang, J., Li, S. F., Cheng, L., Tang, W. Z., and Feng, Y. G. (2018). Upregulation of microRNA24 causes vasospasm following subarachnoid hemorrhage by suppressing the expression of endothelial nitric oxide synthase. Mol. Med. Rep. 18, 1181-1187. doi: 10.3892/mmr.2018.9050

Li, S., Zhu, J., Fu, H., Wan, J., Hu, Z., Liu, S., et al. (2012). Hepatospecific microRNA-122 facilitates accumulation of newly synthesized miRNA through regulating PRKRA. Nucleic Acids Res. 40, 884-891. doi: 10.1093/nar/ gkr715

Li, X., Li, C., Dong, X., and Gou, W. (2014). MicroRNA-155 inhibits migration of trophoblast cells and contributes to the pathogenesis of severe preeclampsia by regulating endothelial nitric oxide synthase. Mol. Med. Rep. 10, 550-554. doi: $10.3892 / \mathrm{mmr} .2014 .2214$

Li, X. H., Xue, W. L., Wang, M. J., Zhou, Y., Zhang, C. C., Sun, C., et al. (2017). H2S regulates endothelial nitric oxide synthase protein stability by promoting microRNA-455-3p expression. Sci. Rep. 7:44807. doi: 10.1038/srep 44807

Li, Y., Ren, Q., Zhu, L., Li, J., Zhang, Y., Zheng, G., et al. (2018). Involvement of methylation of MicroRNA-122, $-125 \mathrm{~b}$ and $-106 \mathrm{~b}$ in regulation of Cyclin G1, CAT-1 and STAT3 target genes in isoniazid-induced liver injury. BMC Pharmacol. Toxicol. 19:11. doi: 10.1186/s40360-018-0201-x

Lim, K. H., Ancrile, B. B., Kashatus, D. F., and Counter, C. M. (2008). Tumour maintenance is mediated by eNOS. Nature 452, 646-649. doi: 10.1038/ nature 06778

Lin, C. C., Law, B. F., and Hettick, J. M. (2020). Acute 4,4'-methylene diphenyl diisocyanate exposure-mediated downregulation of miR-206-3p and miR381-3p activates inducible nitric oxide synthase transcription by targeting calcineurin/NFAT signaling in macrophages. Toxicol. Sci. 173, 100-113. doi: 10.1093/toxsci/kfz215

Ling, H., Fabbri, M., and Calin, G. A. (2013). MicroRNAs and other non-coding RNAs as targets for anticancer drug development. Nat. Rev. Drug Discov. 12, 847-865. doi: $10.1038 / \mathrm{nrd} 4140$

Liu, G. H., Zhou, Z. G., Chen, R., Wang, M. J., Zhou, B., Li, Y., et al. (2013). Serum miR-21 and miR-92a as biomarkers in the diagnosis and prognosis of colorectal cancer. Tumour Biol. 34, 2175-2181. doi: 10.1007/s13277-013-0753-8

Liu, Z., Jiang, Y., Hao, H., Gupta, K., Xu, J., Chu, L., et al. (2007). Endothelial nitric oxide synthase is dynamically expressed during bone marrow stem cell differentiation into endothelial cells. Am. J. Physiol. Heart Circ. Physiol. 293, H1760-H1765. doi: 10.1152/ajpheart.01408.2006

Lozier, A. M., Rich, M. E., Grawe, A. P., Peck, A. S., Zhao, P., Chang, A. T., et al. (2015). Targeting ornithine decarboxylase reverses the LIN28/Let-7 axis and inhibits glycolytic metabolism in neuroblastoma. Oncotarget 6, 196-206. doi: $10.18632 /$ oncotarget. 2768
Lu, Y., Wang, W., Wang, J., Yang, C., Mao, H., Fu, X., et al. (2013). Overexpression of arginine transporter CAT-1 is associated with accumulation of L-arginine and cell growth in human colorectal cancer tissue. PLoS One 8:e73866. doi: 10.1371/journal.pone.0073866

Luo, X., Stock, C., Burwinkel, B., and Brenner, H. (2013). Identification and evaluation of plasma microRNAs for early detection of colorectal cancer. PLoS One 8:e62880. doi: 10.1371/journal.pone.0062880

Lv, Z. C., Fan, Y. S., Chen, H. B., and Zhao, D. W. (2015). Investigation of microRNA-155 as a serum diagnostic and prognostic biomarker for colorectal cancer. Tumour Biol. 36, 1619-1625. doi: 10.1007/s13277-014-2760-9

Ma, G., Pan, P. Y., Eisenstein, S., Divino, C. M., Lowell, C. A., Takai, T., et al. (2011). Paired immunoglobin-like receptor-B regulates the suppressive function and fate of myeloid-derived suppressor cells. Immunity 34, 385-395. doi: 10.1016/j. immuni.2011.02.004

Ma, Q., Wang, Y., Gao, X., Ma, Z., and Song, Z. (2007). L-arginine reduces cell proliferation and ornithine decarboxylase activity in patients with colorectal adenoma and adenocarcinoma. Clin. Cancer Res. 13, 7407-7412. doi: 10.1158/ 1078-0432.CCR-07-0751

Ma, Y., Zhang, P., Wang, F., Zhang, H., Yang, J., Peng, J., et al. (2012). miR-150 as a potential biomarker associated with prognosis and therapeutic outcome in colorectal cancer. Gut 61, 1447-1453. doi: 10.1136/gutjnl-2011-301122

MacMicking, J., Xie, Q. W., and Nathan, C. (1997). Nitric oxide and macrophage function. Annu. Rev. Immunol. 15, 323-350. doi: 10.1146/annurev.immunol.15. 1.323

Malandro, M. S., and Kilberg, M. S. (1996). Molecular biology of mammalian amino acid transporters. Annu. Rev. Biochem. 65, 305-336. doi: 10.1146/ annurev.bi.65.070196.001513

Mandal, S., Mandal, A., Johansson, H. E., Orjalo, A. V., and Park, M. H. (2013). Depletion of cellular polyamines, spermidine and spermine, causes a total arrest in translation and growth in mammalian cells. Proc. Natl. Acad. Sci. U.S.A. 110, 2169-2174. doi: 10.1073/pnas.1219002110

Manna, S. K., Tanaka, N., Krausz, K. W., Haznadar, M., Xue, X., Matsubara, T., et al. (2014). Biomarkers of coordinate metabolic reprogramming in colorectal tumors in mice and humans. Gastroenterology 146, 1313-1324. doi: 10.1053/j. gastro.2014.01.017

Manni, A., Washington, S., Mauger, D., Hackett, D. A., and Verderame, M. F. (2004). Cellular mechanisms mediating the anti-invasive properties of the ornithine decarboxylase inhibitor alpha-difluoromethylornithine (DFMO) in human breast cancer cells. Clin. Exp. Metastasis 21, 461-467. doi: 10.1007/ s10585-004-2724-3

Mao, H. M., Wei, W., Xiong, W. J., Lu, Y., Chen, B. G., and Liu, Z. (2010). Simultaneous determination of l-citrulline and l-arginine in plasma by high performance liquid chromatography. Clin. Biochem. 43, 1141-1147. doi: 10. 1016/j.clinbiochem.2010.05.017

Marigo, I., Zilio, S., Desantis, G., Mlecnik, B., Agnellini, A. H. R., Ugel, S., et al. (2016). T cell cancer therapy requires CD40-CD40L activation of tumor necrosis factor and inducible nitric-oxide-synthase-producing dendritic cells. Cancer Cell 30, 377-390. doi: 10.1016/j.ccell.2016.08.004

Modolell, M., Corraliza, I. M., Link, F., Soler, G., and Eichmann, K. (1995). Reciprocal regulation of the nitric oxide synthase/arginase balance in mouse bone marrow-derived macrophages by $\mathrm{TH} 1$ and $\mathrm{TH} 2$ cytokines. Eur. J. Immunol. 25, 1101-1104. doi: 10.1002/eji.1830250436

Morris, S. M. Jr. (2010). Arginine: master and commander in innate immune responses. Sci. Signal. 3:e27. doi: 10.1126/scisignal.3135pe27

Muxel, S. M., Acuna, S. M., Aoki, J. I., Zampieri, R. A., and Floeter-Winter, L. M. (2018). Toll-like receptor and miRNA-let-7e expression alter the inflammatory response in leishmania amazonensis-infected macrophages. Front. Immunol. 9:2792. doi: 10.3389/fimmu.2018.02792

Muxel, S. M., Laranjeira-Silva, M. F., Zampieri, R. A., and Floeter-Winter, L. M. (2017). Leishmania (Leishmania) amazonensis induces macrophage miR-294 and miR-721 expression and modulates infection by targeting NOS2 and L-arginine metabolism. Sci. Rep. 7:44141. doi: 10.1038/srep 44141

Nakanishi, I., Onoda, N., Chung, Y. S., Maeda, K., Kubo, T., Kato, Y., et al. (1993). [Analysis of cell proliferation in endoscopically biopsied specimen of the stomal mucosa of the remnant stomach-with special reference to cell cycle and ODC activity]. Gan to kagaku ryoho. Cancer Chemother. 20, 752-755. 
Ng, E. K., Chong, W. W., Jin, H., Lam, E. K., Shin, V. Y., Yu, J., et al. (2009). Differential expression of microRNAs in plasma of patients with colorectal cancer: a potential marker for colorectal cancer screening. Gut 58, 1375-1381. doi: 10.1136/gut.2008.167817

Niu, Y., Jin, Y., Deng, S. C., Deng, S. J., Zhu, S., Liu, Y., et al. (2018). MiRNA646-mediated reciprocal repression between HIF-1alpha and MIIP contributes to tumorigenesis of pancreatic cancer. Oncogene 37, 1743-1758. doi: 10.1038/ s41388-017-0082-2

Norian, L. A., Rodriguez, P. C., O’Mara, L. A., Zabaleta, J., Ochoa, A. C., Cella, M., et al. (2009). Tumor-infiltrating regulatory dendritic cells inhibit CD8+ $\mathrm{T}$ cell function via L-arginine metabolism. Cancer Res. 69, 3086-3094. doi: 10.1158/0008-5472.CAN-08-2826

Ogata-Kawata, H., Izumiya, M., Kurioka, D., Honma, Y., Yamada, Y., Furuta, K., et al. (2014). Circulating exosomal microRNAs as biomarkers of colon cancer. PLoS One 9:e92921. doi: 10.1371/journal.pone.0092921

Okugawa, Y., Grady, W. M., and Goel, A. (2015). Epigenetic alterations in colorectal cancer: emerging biomarkers. Gastroenterology 149:e12. doi: 10.1053/ j.gastro.2015.07.011

Ouyang, M., Su, W., Xiao, L., Rao, J. N., Jiang, L., Li, Y., et al. (2015). Modulation by miR-29b of intestinal epithelium homoeostasis through the repression of menin translation. Biochem. J. 465, 315-323. doi: 10.1042/BJ201 41028

Palacin, M., Estevez, R., Bertran, J., and Zorzano, A. (1998). Molecular biology of mammalian plasma membrane amino acid transporters. Physiol. Rev. 78, 969-1054. doi: 10.1152/physrev.1998.78.4.969

Patil, M. D., Bhaumik, J., Babykutty, S., Banerjee, U. C., and Fukumura, D. (2016). Arginine dependence of tumor cells: targeting a chink in cancer's armor. Oncogene 35, 4957-4972. doi: 10.1038/onc.2016.37

Paz, E. A., LaFleur, B., and Gerner, E. W. (2014). Polyamines are oncometabolites that regulate the LIN28/let-7 pathway in colorectal cancer cells. Mol. Carcinog. 53(Suppl. 1), E96-E106. doi: 10.1002/mc.22051

Pearce, L. L., Zheng, X., Martinez-Bosch, S., Kerr, P. P., Khlangwiset, P., Epperly, M. W., et al. (2012). L-arginine is a radioprotector for hematopoietic progenitor cells. Radiation Res. 177, 792-803. doi: 10.1667/rr1281.1

Penarando, J., Lopez-Sanchez, L. M., Mena, R., Guil-Luna, S., Conde, F., Hernandez, V., et al. (2018). A role for endothelial nitric oxide synthase in intestinal stem cell proliferation and mesenchymal colorectal cancer. BMC Biol. 16:3. doi: 10.1186/s12915-017-0472-5

Perske, C., Lahat, N., Sheffy Levin, S., Bitterman, H., Hemmerlein, B., and Rahat, M. A. (2010). Loss of inducible nitric oxide synthase expression in the mouse renal cell carcinoma cell line RENCA is mediated by microRNA miR-146a. Am. J. Pathol. 177, 2046-2054. doi: 10.2353/ajpath.2010.091111

Phillips, M. M., Sheaff, M. T., and Szlosarek, P. W. (2013). Targeting argininedependent cancers with arginine-degrading enzymes: opportunities and challenges. Cancer Res. Treat. 45, 251-262. doi: 10.4143/crt.2013.45.4.251

Pritchard, C. C., and Grady, W. M. (2011). Colorectal cancer molecular biology moves into clinical practice. Gut 60, 116-129. doi: 10.1136/gut.2009.206250

Pu, X. X., Huang, G. L., Guo, H. Q., Guo, C. C., Li, H., Ye, S., et al. (2010). Circulating miR-221 directly amplified from plasma is a potential diagnostic and prognostic marker of colorectal cancer and is correlated with p53 expression. J. Gastroenterol. Hepatol. 25, 1674-1680. doi: 10.1111/j.1440- 1746. 2010.06417.x

Rasheed, Z., Al-Shobaili, H. A., Rasheed, N., Mahmood, A., and Khan, M. I. (2016). MicroRNA-26a-5p regulates the expression of inducible nitric oxide synthase via activation of NF-kappaB pathway in human osteoarthritis chondrocytes. Arch. Biochem. Biophys. 594, 61-67. doi: 10.1016/j.abb.2016. 02.003

Rebsamen, M., Pochini, L., Stasyk, T., de Araujo, M. E., Galluccio, M., Kandasamy, R. K., et al. (2015). SLC38A9 is a component of the lysosomal amino acid sensing machinery that controls mTORC1. Nature 519, 477-481. doi: 10.1038/ nature 14107

Reilly, S. N., Liu, X., Carnicer, R., Recalde, A., Muszkiewicz, A., Jayaram, R., et al. (2016). Up-regulation of miR-31 in human atrial fibrillation begets the arrhythmia by depleting dystrophin and neuronal nitric oxide synthase. Sci. Transl. Med. 8:340ra74. doi: 10.1126/scitranslmed.aac4296

Rodriguez, P. C., Quiceno, D. G., and Ochoa, A. C. (2007). L-arginine availability regulates T-lymphocyte cell-cycle progression. Blood 109, 1568-1573. doi: 10. 1182/blood-2006-06-031856
Rodriguez, P. C., Zea, A. H., DeSalvo, J., Culotta, K. S., Zabaleta, J., Quiceno, D. G., et al. (2003). L-arginine consumption by macrophages modulates the expression of CD3 zeta chain in T lymphocytes. J. Immunol. 171, 1232-1239. doi: 10.4049/jimmunol.171.3.1232

Sadanandam, A., Lyssiotis, C. A., Homicsko, K., Collisson, E. A., Gibb, W. J. Wullschleger, S., et al. (2013). A colorectal cancer classification system that associates cellular phenotype and responses to therapy. Nat. Med. 19, 619-625. doi: $10.1038 / \mathrm{nm} .3175$

Saxton, R. A., Knockenhauer, K. E., Wolfson, R. L., Chantranupong, L., Pacold, M. E., Wang, T., et al. (2016). Structural basis for leucine sensing by the Sestrin2-mTORC1 pathway. Science 351, 53-58. doi: 10.1126/science.aad2087

Scalavino, V., Liso, M., Cavalcanti, E., Gigante, I., Lippolis, A., Mastronardi, M., et al. (2020). miR-369-3p modulates inducible nitric oxide synthase and is involved in regulation of chronic inflammatory response. Sci. Rep. 10:15942. doi: 10.1038/s41598-020-72991-8

Schetter, A. J., Leung, S. Y., Sohn, J. J., Zanetti, K. A., Bowman, E. D., Yanaihara, N., et al. (2008). MicroRNA expression profiles associated with prognosis and therapeutic outcome in colon adenocarcinoma. JAMA 299, 425-436. doi: 10. 1001/jama.299.4.425

Scuoppo, C., Miething, C., Lindqvist, L., Reyes, J., Ruse, C., Appelmann, I., et al. (2012). A tumour suppressor network relying on the polyamine-hypusine axis. Nature 487, 244-248. doi: 10.1038/nature11126

Sektioglu, I. M., Carretero, R., Bender, N., Bogdan, C., Garbi, N., Umansky, V., et al. (2016). Macrophage-derived nitric oxide initiates T-cell diapedesis and tumor rejection. Oncoimmunology 5:e1204506. doi: 10.1080/2162402X.2016.12 04506

Selvi, I., Basar, H., Baydilli, N., Murat, K., and Kaymaz, O. (2019). The importance of plasma arginine level and its downstream metabolites in diagnosing prostate cancer. Int. Urol. Nephrol. 51, 1975-1983. doi: 10.1007/s11255-019-02261-8

Seo, S. K., Yang, W., Park, Y. M., Lee, W. T., Park, K. A., and Lee, J. E. (2013). Overexpression of human arginine decarboxylase rescues human mesenchymal stem cells against $\mathrm{H}(2) \mathrm{O}(2)$ toxicity through cell survival protein activation. J. Korean Med. Sci. 28, 366-373. doi: 10.3346/jkms.2013.28.3.366

Spinelli, V., Vona, A., Corti, F., Diolaiuti, L., Zanardelli, M., Sartiani, L., et al. (2016). Role of nitric oxide, nitric oxide synthase, soluble guanylyl cyclase, and cGMP-dependent protein kinase I in mouse stem cell cardiac development. Stem Cells Int. 2016:2868323. doi: 10.1155/2016/2868323

Su, A. I., Wiltshire, T., Batalov, S., Lapp, H., Ching, K. A., Block, D., et al. (2004). A gene atlas of the mouse and human protein-encoding transcriptomes. Proc. Natl. Acad. Sci. U.S.A. 101, 6062-6067. doi: 10.1073/pnas.0400782101

Sun, H. X., Zeng, D. Y., Li, R. T., Pang, R. P., Yang, H., Hu, Y. L., et al. (2012). Essential role of microRNA-155 in regulating endothelium-dependent vasorelaxation by targeting endothelial nitric oxide synthase. Hypertension 60 , 1407-1414. doi: 10.1161/HYPERTENSIONAHA.112.197301

Szlosarek, P. W. (2014). Arginine deprivation and autophagic cell death in cancer. Proc. Natl. Acad. Sci. U.S.A. 111, 14015-14016. doi: 10.1073/pnas.1416560111

Tham, M., Tan, K. W., Keeble, J., Wang, X., Hubert, S., Barron, L., et al. (2014). Melanoma-initiating cells exploit M2 macrophage TGFbeta and arginase pathway for survival and proliferation. Oncotarget 5, 12027-12042. doi: 10 . 18632/oncotarget.2482

Toiyama, Y., Takahashi, M., Hur, K., Nagasaka, T., Tanaka, K., Inoue, Y., et al. (2013). Serum miR-21 as a diagnostic and prognostic biomarker in colorectal cancer. J. Natl. Cancer Inst. 105, 849-859. doi: 10.1093/jnci/djt101

Tu, M. J., Duan, Z., Liu, Z., Zhang, C., Bold, R. J., Gonzalez, F. J., et al. (2020). MicroRNA-1291-5p sensitizes pancreatic carcinoma cells to arginine deprivation and chemotherapy through the regulation of arginolysis and glycolysis. Mol. Pharmacol. 98, 686-694. doi: 10.1124/molpharm.120.000130

Wang, C., Yang, Y., Li, M., Liu, X., Wang, Q., Xin, W., et al. (2017). Safflor yellow $\mathrm{B}$ reduces hypoxia-mediated vasoconstriction by regulating endothelial micro ribonucleic acid/nitric oxide synthase signaling. Oncotarget 8, 93551-93566. doi: 10.18632 /oncotarget.20133

Wang, J., Huang, S. K., Zhao, M., Yang, M., Zhong, J. L., Gu, Y. Y., et al. (2014). Identification of a circulating microRNA signature for colorectal cancer detection. PLoS One 9:e87451. doi: 10.1371/journal.pone.0087451

Wang, M., Sun, L., Ding, W., Cai, S., and Zhao, Q. (2019). Ablation alleviates atrial fibrillation by regulating the signaling pathways of endothelial nitric oxide synthase/nitric oxide via miR-155-5p and miR-24-3p. J. Cell. Biochem. 120, 4451-4462. doi: 10.1002/jcb.27733 
Wang, S., Tsun, Z. Y., Wolfson, R. L., Shen, K., Wyant, G. A., Plovanich, M. E., et al. (2015). Metabolism. Lysosomal amino acid transporter SLC38A9 signals arginine sufficiency to mTORC1. Science 347, 188-194. doi: 10.1126/science. 1257132

Wang, Y., Zhao, P., Qian, D., Hu, M., Zhang, L., Shi, H., et al. (2017). MicroRNA613 is downregulated in HCMV-positive glioblastoma and inhibits tumour progression by targeting arginase-2. Tumour Biol. 39:1010428317712512. doi: $10.1177 / 1010428317712512$

Wolfson, R. L., Chantranupong, L., Saxton, R. A., Shen, K., Scaria, S. M., Cantor, J. R., et al. (2016). Sestrin2 is a leucine sensor for the mTORC1 pathway. Science 351, 43-48. doi: 10.1126/science.aab2674

Wu, C. W., Ng, S. S., Dong, Y. J., Ng, S. C., Leung, W. W., Lee, C. W., et al. (2012). Detection of miR-92a and miR-21 in stool samples as potential screening biomarkers for colorectal cancer and polyps. Gut 61, 739-745. doi: 10.1136/gut. 2011.239236

Wu, G., Bazer, F. W., Davis, T. A., Kim, S. W., Li, P., Marc Rhoads, J., et al. (2009). Arginine metabolism and nutrition in growth, health and disease. Amino Acids 37, 153-168. doi: 10.1007/s00726-008-0210-y

$\mathrm{Xu}$, H., Washington, S., Verderame, M. F., and Manni, A. (2008). Role of nonreceptor and receptor tyrosine kinases (TKs) in the antitumor action of alphadifluoromethylornithine (DFMO) in breast cancer cells. Breast Cancer Res. Treat. 112, 255-261. doi: 10.1007/s10549-007-9866-3

Yachimovich-Cohen, N., Even-Ram, S., Shufaro, Y., Rachmilewitz, J., and Reubinoff, B. (2010). Human embryonic stem cells suppress T cell responses via arginase I-dependent mechanism. J. Immunol. 184, 1300-1308. doi: 10.4049/ jimmunol.0804261

Yan, L., Hao, H., Elton, T. S., Liu, Z., and Ou, H. (2011). Intronic microRNA suppresses endothelial nitric oxide synthase expression and endothelial cell proliferation via inhibition of STAT3 signaling. Mol. Cell. Biochem. 357, 9-19. doi: 10.1007/s11010-011-0870-X

Yoo, H., Kim, J., Lee, A. R., Lee, J. M., Kim, O. J., Kim, J. K., et al. (2019). Alteration of microRNA 340-5p and arginase- 1 expression in peripheral blood cells during acute ischemic stroke. Mol. Neurobiol. 56, 3211-3221. doi: 10.1007/s12035-0181295-2
Zanutto, S., Pizzamiglio, S., Ghilotti, M., Bertan, C., Ravagnani, F., Perrone, F., et al. (2014). Circulating miR-378 in plasma: a reliable, haemolysis-independent biomarker for colorectal cancer. Br. J. Cancer 110, 1001-1007. doi: 10.1038/bjc. 2013.819

Zell, J. A., Lin, B. S., Ziogas, A., and Anton-Culver, H. (2012). Meat consumption, ornithine decarboxylase gene polymorphism, and outcomes after colorectal cancer diagnosis. J. Carcinogenesis 11:17. doi: 10.4103/1477-3163.104004

Zhang, H., Wang, L., Peng, F., Wang, X., and Gong, H. (2020). L-arginine ameliorates high-fat diet-induced atherosclerosis by downregulating miR-221. BioMed. Res. Int. 2020:4291327. doi: 10.1155/2020/4291327

Zhang, J., Zhao, F., Yu, X., Lu, X., and Zheng, G. (2015). MicroRNA-155 modulates the proliferation of vascular smooth muscle cells by targeting endothelial nitric oxide synthase. Int. J. Mol. Med. 35, 1708-1714. doi: 10.3892/ijmm.2015. 2181

Zhang, J. X., Song, W., Chen, Z. H., Wei, J. H., Liao, Y. J., Lei, J., et al. (2013). Prognostic and predictive value of a microRNA signature in stage II colon cancer: a microRNA expression analysis. Lancet Oncol. 14, 1295-1306. doi: 10.1016/S1470-2045(13)70491-1

Zhu, H., Vishwamitra, D., Curry, C. V., Manshouri, R., Diao, L., Khan, A., et al. (2013). NPM-ALK up-regulates iNOS expression through a STAT3/microRNA26a-dependent mechanism. J. Pathol. 230, 82-94. doi: 10.1002/path. 4171

Conflict of Interest: The authors declare that the research was conducted in the absence of any commercial or financial relationships that could be construed as a potential conflict of interest.

Copyright (c) $2021 \mathrm{Du}$ and Han. This is an open-access article distributed under the terms of the Creative Commons Attribution License (CC BY). The use, distribution or reproduction in other forums is permitted, provided the original author(s) and the copyright owner(s) are credited and that the original publication in this journal is cited, in accordance with accepted academic practice. No use, distribution or reproduction is permitted which does not comply with these terms. 